\title{
REINFORCEMENT OF CHARACTER EDUCATION THROUGH CREATING QUIZ "SIAP SIAP AKU BISA" FOR ELEMENTARY SCHOOL STUDENTS
}

\author{
Hendi Prihanto, Prasriana Fitriesti, Usmar, Rajab Ritonga \\ Universitas Prof. Dr. Moestopo (Beragama), Indonesia \\ hp_torana@yahoo.com
}

\begin{abstract}
The goal of national education is the development of students' potentials to become Indonesian people who have character, life skills, and are fully Indonesian nationalism. The purpose of the national education was clearly translated by the Ministry of Education and Culture through the Reinforcement of Character Education program for students at each level of education unit. Reinforcement of character education can be accelerated through the socialization of Reinforcement of Character Education for students, teachers and parents. As an implementation of this socialization, the Directorate of Elementary School Development through the Sub-Directorate of Students held Quizzes for Elementary School Students in 20 locations starting in March 2018 under the name "Kuis SiapSiap Aku Bisa". This quiz is carried out with a television show quiz production model that involves audio visual by the experts in their fields as a means to shape the character of elementary school students to become Indonesian people who have belief, faith, and knowledge to become fully Indonesian. The results of this activity have had an enormous impact and impact on the mental development and behavior of participants to become more confident and have the courage to appear in public. For this reason, this activity in the future must be carried out in a sustainable manner considering the results obtained are very important and positive.
\end{abstract}

Keywords: Implementation, Socialization, PPK, Elementary School Students, Indonesian Culture.

\section{INTRODUCTION}

In Law Number 20 of 2003 regarding the National Education System, Article 3 states that national education aims to develop the potential of students to become human beings who have faith and fear of God Almighty, are noble, healthy, knowledgeable, competent, creative, independent, and become democratic and responsible citizens. Ministry of Education and Culture translates this national education goal through the Reinforcement of Character Education (Penguatan Pendidikan Karakter/PPK) program for students at each level of education unit.

In accordance with the direction of the Minister of Education and Culture regarding the importance of reinforcing character education for students, all elements involved in the national education process in this case students, teachers, parents, and related parties need to understand the reinforcement of character education which is the National Mental Revolution Movement (Gerakan Nasional Revolusi Mental/GNRM), namely changes in ways of thinking, behaving, and acting for the better.

The main values of PPK are religious, nationalist, independent, mutual cooperation, integrity (https://cerdasberkarakter.kemdikbud.go.id/?page_id=132). Therefore, PPK socialization can be implemented through activities that involve students, teachers, and parents. One of the programmed activities is the Elementary School quiz called Character Smart Indonesian Students Quiz, "Siap-Siap Aku Bisa". To spread the impact of this activity, it is broadcast through national television stations. As an important part of the quiz implementation, it is necessary to compile the questions used in the program.

The Quiz "Siap-Siap Aku Bisa" 2018 Elementary School Students aims to socialize the Character Education Reinforcement Program, strengthen students' character education through the demonstration of knowledge, attitudes, and skills in the quiz, and produce Quiz show "Siap-Siap Aku Bisa" for 2018Elementary School Students. Later, this activity can be expected to socialize the PPK program through the Quiz "Siap-Siap Aku Bisa" 2018 Elementary School Students, strengthen the character of students, and the production of the Quiz "Siap-Siap Aku Bisa” 2018 Elementary School Students.

\section{IMPLEMENTATION METHOD}

The target in this activity is elementary school students scattered in 20 locations in Java from March 2018 to March 2019. The Committee of the Quiz "Siap-Siap Aku Bisa" 2018 Elementary School Students consists of creative team, production crew and Elementary School development. The participants supporting the implementation of this quiz is the Directorate of Elementary Education Development of Ministry of Education and Culture in collaboration with Education and Culture Office in each municipality or regency to select and coordinate 10 
Elementary Schools as the quiz participants, medical team for first aid of students' health condition during the quiz and security team by involving the Police Unit to support the order of the quiz. Not only that, this quiz also invites competent and accomplished judges, such as Shahnaz Haque, Indonesian Intelligence Princess in 1995 and Measles Ambassador for UNICEF in 2007, Ria Enez, a radio announcer, singer, host with Suzan doll and teacher representatives from every Municipality or Regency, in addition to the PKM UPDM (B).

The method of delivering information is done through quizzes with 4 segments. The first segment is Get to Know the Figure, followed by participants in rows 1 and 2. Each team will have the opportunity to answer 4 questions in a race. Then the judges comment and give a score to the team that can answer the question. The second segment is My Good Attitude. Participants who take part in answering questions are participants in rows 3 and 4 . Each team will have the opportunity to answer 4 questions in a race. The rule of the game is that participants must pay attention to a video until finish and give an opinion about what happened in the video that reflect good behavior. Then the judges will comment and give a score to the team that can answer the question.

The third segment is My Beloved Country. Participants who take part in answering questions are participants in rows 5 and 6. Participants must answer what they know about tourist attractions, historical sites, and souvenirs from the city or regency that will later be read by the Host according to the video to be shown. In addition, participants will not only be tested on their insight and knowledge, but also their skills and teamwork. In the last segment, participants will be tested for creativity and presentation in a game. Each group prepares 5 participants to join the segment Let's Play. Then the judges will comment and give an assessment for each team.

After the 4 segments have been completed, the judges give an announcement of the scores of the best five to the first. Then the participants and judges are invited to come to the center of the stage. Prizes will be represented by the Ministry of Education and Culture.
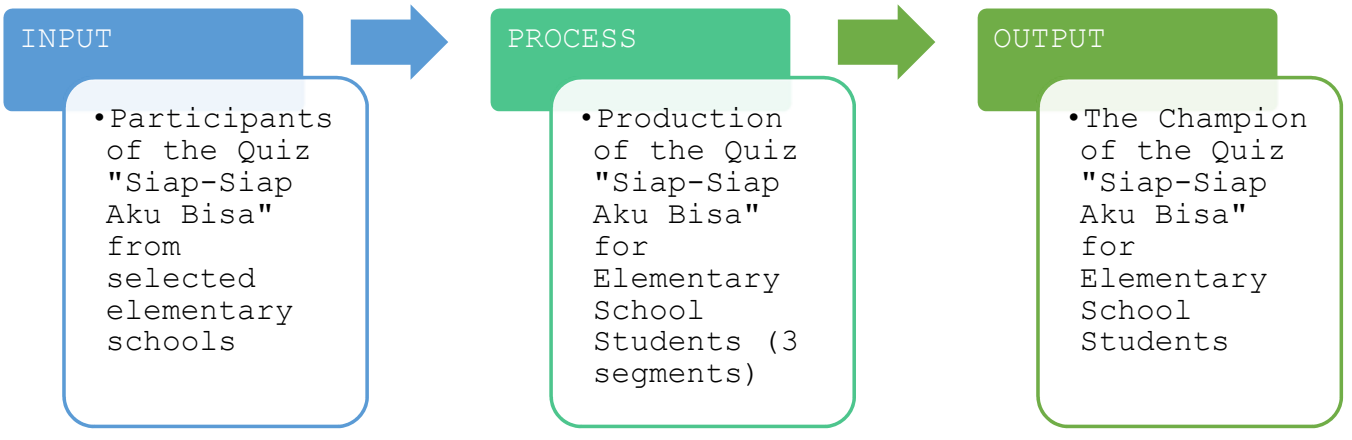

Figure 1.1 Scenario of Activity

Picture 1.1 Opening Session

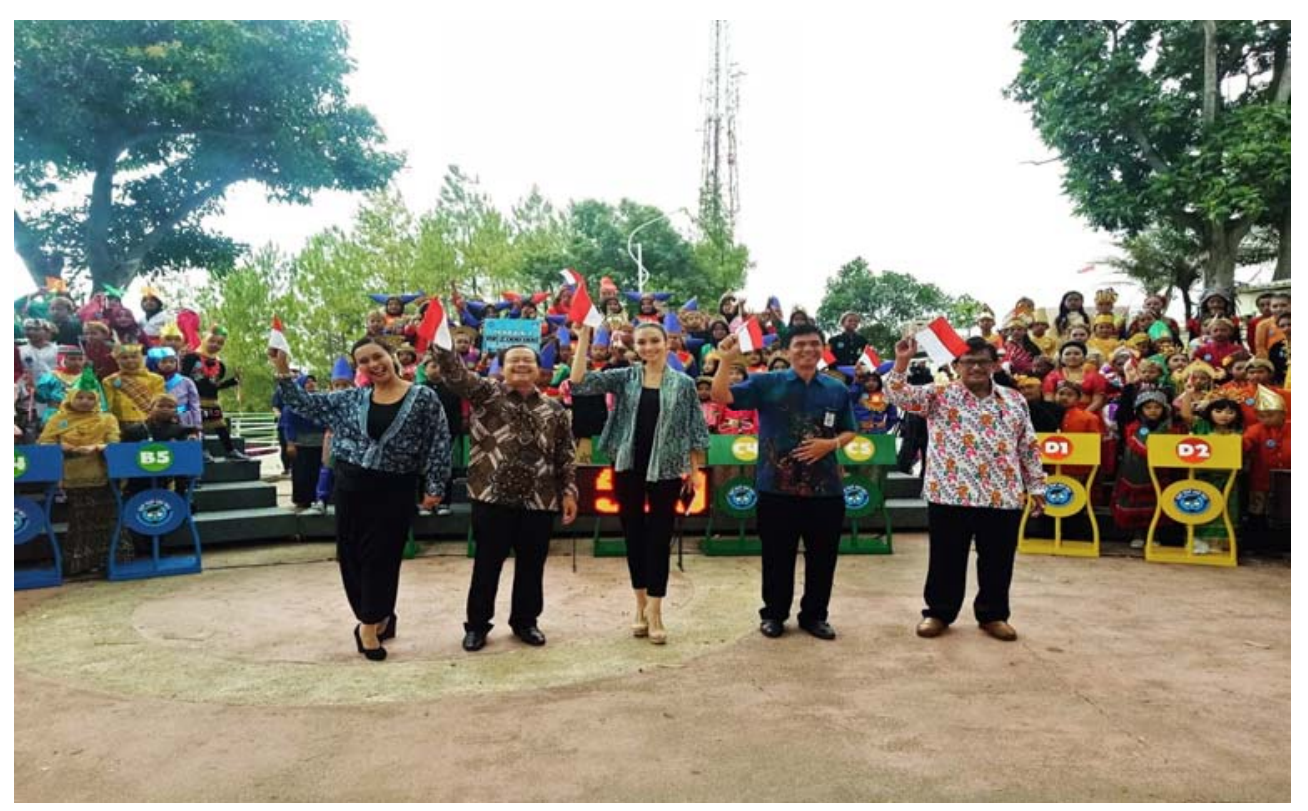

Picture 1.2 Training Session 


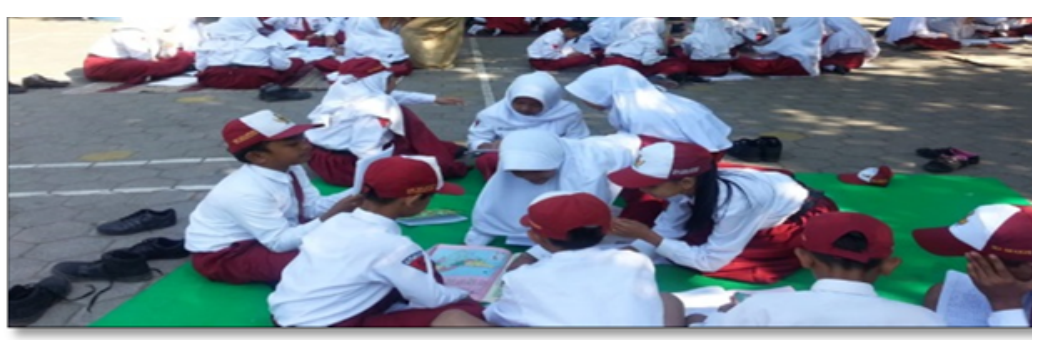

Picture 1.3 Motivation Session

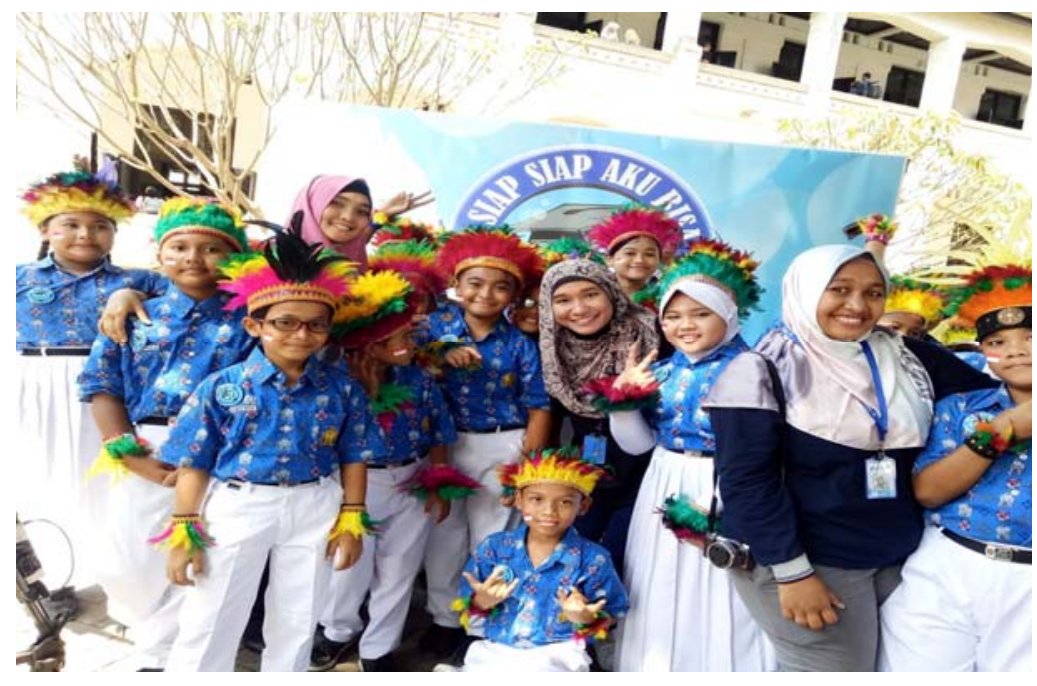

Picture 1.4 Winner announcement

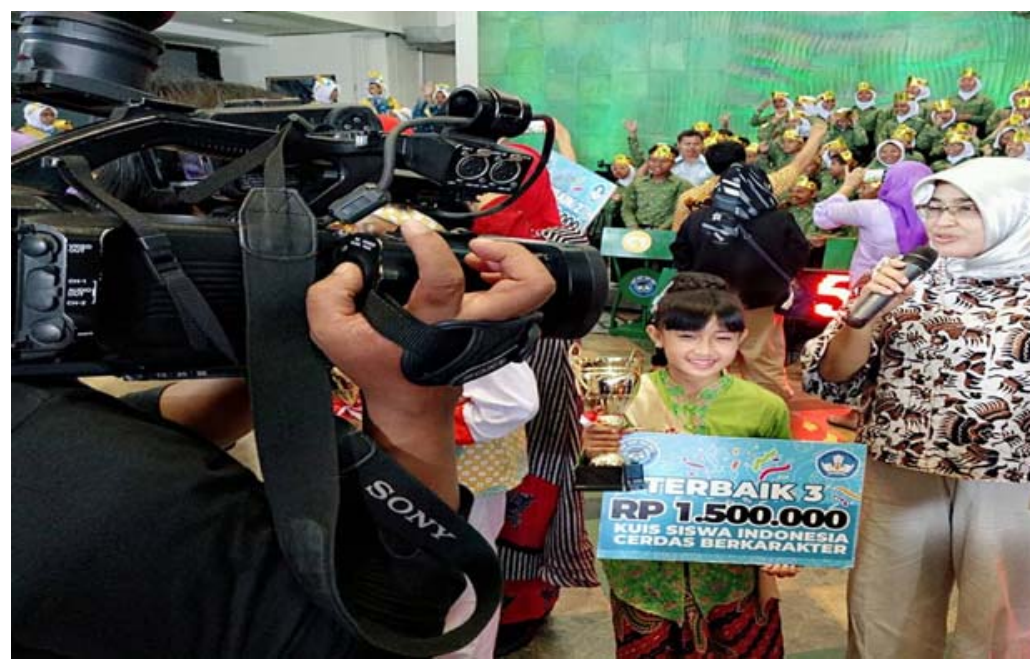

Picture 1.5 Winner Announcement 


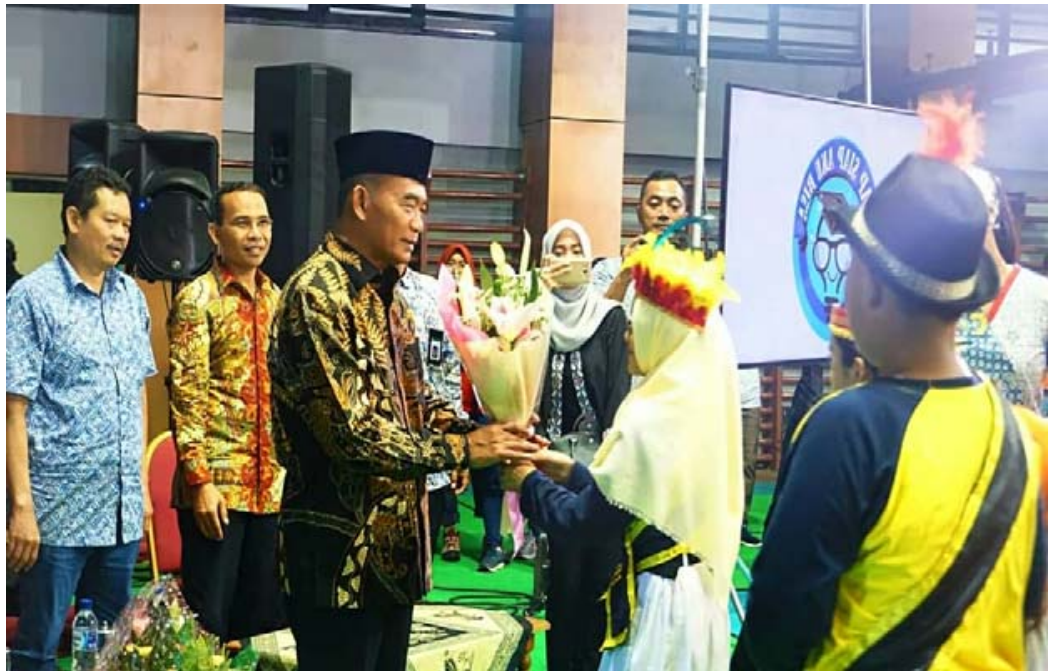

Picture 1.6 Participants with Javanese Culture

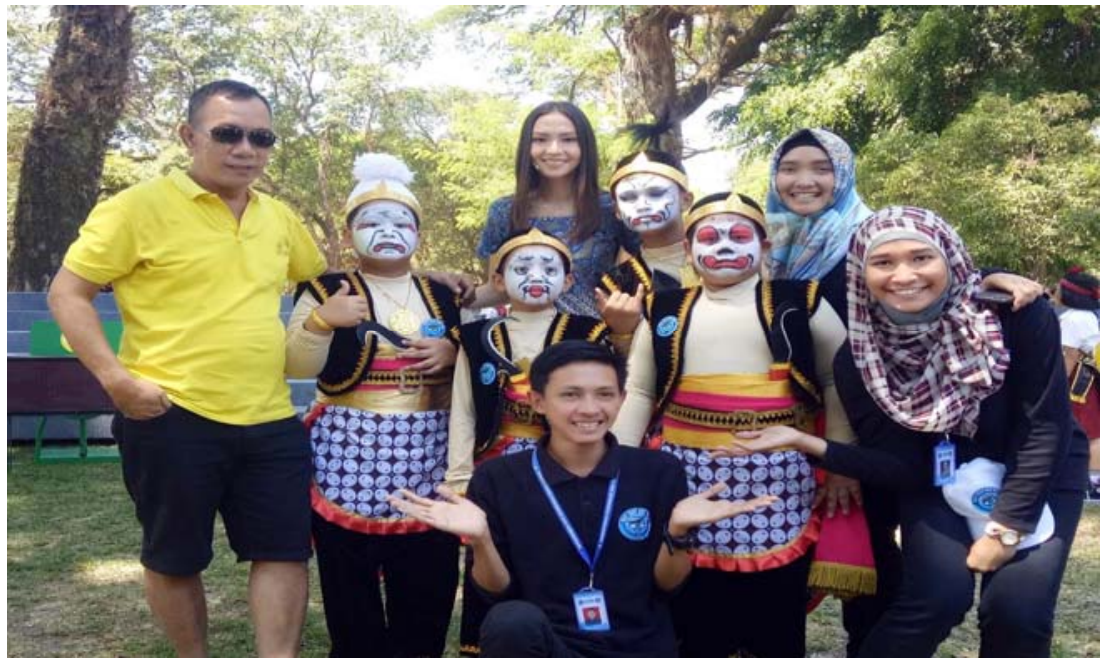

\section{RESULTS AND DISCUSSION}

The Quiz "Siap-Siap Aku Bisa" 2018 Elementary School Students was taken with the following processes: (1) Registration was facilitated by the committee; (2) The opening ceremony was attended by officials from the Directorate of Elementary School Development of Ministry of Education and Culture Guidance, officials from the Municipality/Regency Government, Chief of Police; (3) The quiz was carried out smoothly and under control. Participants were very enthusiastic and full of fun. Supporters of both teachers and parents were also very eager to provide support to their sons and daughters who were demonstrating their knowledge and skills; (4) Overall, the Quiz "Siap-Siap Aku Bisa" 2018 Elementary School Students spread in 20 locations in Java starting in March 2018 could be carried out according to plan.

\section{CONCLUSION}

The Quiz "Siap-Siap Aku Bisa" 2018 Elementary School Students is an effort of the Directorate of Elementary School Development to reinforce the nation's character education towards elementary school students and as a means to socialize the importance of Reinforcement of Character Education in elementary schools to teachers, parents, and the community in general. With the implementation of community service, this brings benefits to all teachers, parents, and the community in general. So then it would be better for this activity to be carried out continuously, not only in Java but also outside Java.

\section{REFERENCES}

https://kelembagaan.ristekdikti.go.id/wp-content/uploads/2016/08/UU_no_20_th_2003.pdf https://cerdasberkarakter.kemdikbud.go.id/?page_id=132 